\title{
ANALISIS PENGARUH NIM, BOPO, LDR, DAN NPL TERHADAP PROFITABILITAS (Studi Kasus Pada Bank Umum Yang Listed Di Bursa Efek Indonesia Periode 2014-2018)
}

\author{
Wulandari Danu Lestari*) \\ R. Gunawan Setianegara**) \\ *)wulandanul8@gmail.com
}

\begin{abstract}
This research aims to determine the effect of Net Interest Margin (NIM), Operation Expenses to Operations Income (BOPO), Loan to Deposit Ratio (LDR), and Non Performing Loan (NPL) toward Profitability (Case Study on the Commercial Banks that Listed in Indonesia Stock Exchange period 2014-2018).

In this research the sampling technique used was purposive sampling technique and managed to obtained 13 banks. Secondary data used were obtained from financial reports published from the official website of the Otoritas Jasa Keuangan (OJK). Methods of data analysis used in this study is the analysis of multiple linear regression with a level of significance of $5 \%$.

The results showed that the variables NIM, BOPO, LDR, and NPL simultaneously have significant effect to Profitability. Based on the t-test results it can be concluded that the variables NIM and BOPO have significant effect while LDR, and NPL have not significant effect to Profitability. The results obtained by multiple linear regression analysis Adjusted R2 of 0.976, this shows that the contribution of independent variables in explaining the dependent variable is $97,6 \%$ and the remaining is explained by other variables that are not examined.
\end{abstract}

Keywords : Profitability, ROA, NIM, BOPO, LDR and NPL

*) Mahasiswa Tugas Akhir Prodi Keuangan dan Perbankan Jurusan Akuntansi Politeknik Negeri Semarang

**) Dosen Jurusan Akuntansi Politeknik Negeri Semarang

\section{PENDAHULUAN}

\section{Latar Belakang Masalah}

Pertumbuhan laba bank pada Oktober 2018 mengalami perlambatan. Ada sepuluh bank besar yang didasarkan pada peringkat total aset bank, yaitu BRI, Bank Mandiri, BCA, BNI, BTN, Bank CIMB Niaga, Bank Panin, Bank OCBC NISP, Maybank Indonesia dan Bank Permata. Sepuluh bank besar ini mencatat realisasi laba bersih sebesar Rp 89,4 triliun atau naik $12,55 \%$ secara tahunan atau year on year (yoy). Pertumbuhan laba bank Oktober 2018 ini melambat dibandingkan Oktober 2017 yang sebesar 16,8\% yoy. Perlambatan ini disebabkan karena penurunan biaya operasional bank pada Oktober 2018 lebih rendah 3,21\% yoy dibandingkan periode yang sama tahun 2017 sebesar 9,44\% yoy. Jika dilihat dari fungsi intermediasi, pertumbuhan kredit sepuluh bank besar sampai Oktober 2018 naik 14,9\% yoy, lebih tinggi dibandingkan periode yang sama tahun 2017 sebesar 8,5\%. Pertumbuhan kredit ini menyebabkan pendapatan bunga bersih bank pada Oktober 2018 5,4\% yoy lebih tinggi 
dibandingkan periode yang sama tahun 2017 sebesar 4,15\% yoy (Kontan.co.id, diunduh tanggal 3 Januari 2019 jam 21.42 WIB).

Profitabilitas bank diukur dengan menggunakan ROA (Return On Asset). Berikut merupakan porsi perkembangan Return On Assets (ROA) pada Bank Umum yang Listed di Bursa Efek Indonesia tahun 2014-2018:

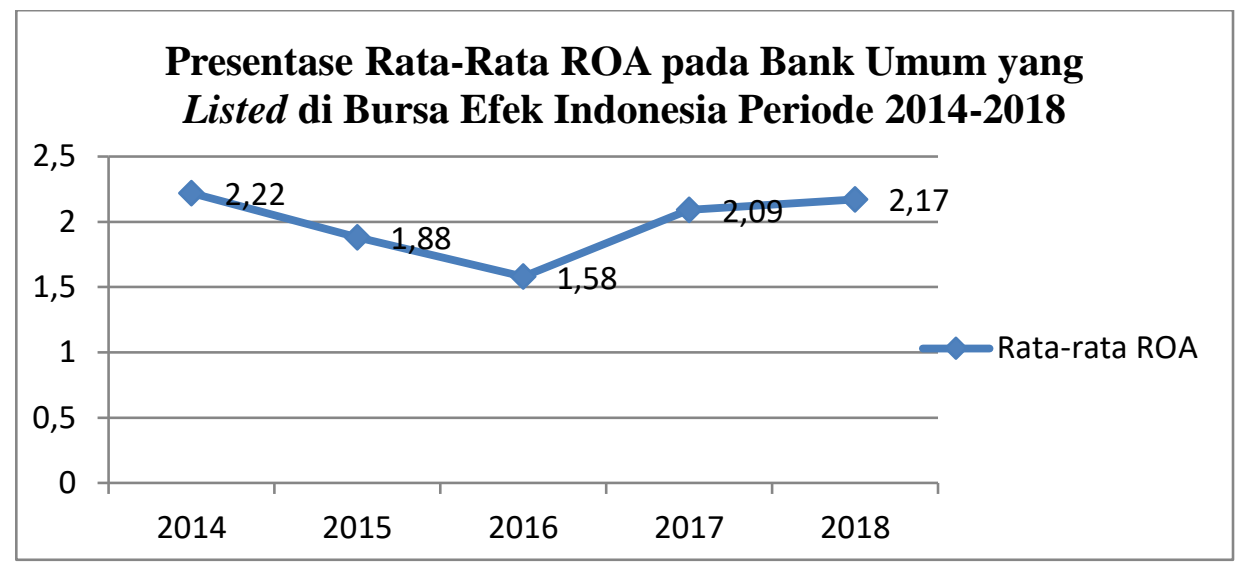

Sumber: Laporan Tahunan Tiap Bank (Diolah)

Gambar 1 Grafik Perkembangan Rata Rata-rata Return On Assets (ROA) pada Bank Umum yang Listed di Bursa Efek Indonesia Periode 2014-2018

Selain fenomena gap di atas, hasil penelitian mengenai profitabilitas (ROA) masih ditemukan perbedaan hasil seperti pada penelitian Romasta (2017), Sianturi (2012), Ponco (2008), Nusatara (2009), Arifianto (2016), Rahman (2009), Alifah (2014), dan Santosa (2012) Sehingga terdapat perbedaan hasil penelitian (research gap).

\section{Rumusan Masalah}

Berdasarkan latar belakang diatas, maka dapat dirumuskan masalah dari penelitian ini adalah apakah Net Interest Margin (NIM), Biaya Operasional dibandingkan Pendapatan Operasional (BOPO), Loan to Deposit Ratio (LDR) dan Non Performing Loan (NPL) mempunyai pengaruh terhadap Profitabilitas. Maka penelitian ini ditujukan untuk melakukan penelitian kembali tentang pengaruh NIM, BOPO, LDR dan NPL.

\section{KAJIAN TEORI}

\section{Pengaruh Net Interest Margin (NIM) Terhadap Return On Assets (ROA)}

Net Interest Margin (NIM) merupakan rasio yang menunjukkan kemampuan manajemen bank dalam mengelola aktiva produktifnya untuk menghasilkan pendapatan bunga bersih. Pendapatan bunga bersih diperoleh dari pendapatan bunga dikurangi beban bunga. Semakin besar rasio ini maka meningkatnya pendapatan bunga atas aktiva produktif yang dikelola bank sehingga kemungkinan bank dalam kondisi bermasalah semakin kecil. Semakin besar rasio ini 
maka meningkatnya pendapatan bunga atas aktiva produktif yang dikelola bank sehingga kemungkinan bank dalam kondisi bermasalah semakin kecil (Almilia dan Herdiningtyas, 2005 dalam Mismiwati, 2016). Menurut penelitian yang telah dilakukan oleh Christiano, dkk (2014) dan Purwoko dan Sudiyatno (2013) menyatakan bahwa NIM berpengaruh signifikan positif terhadap ROA. Berdasarkan penelitian-penelitian terdahulu terdahulu maka diduga Net Interest Margin (NIM) secara parsial berpengaruh terhadap Profitabilitas pada Bank Umum yang Listed di Bursa Efek Indonesia Periode 2014-2018.

\section{Pengaruh Biaya Operasional dengan Pendapatan Operasional (BOPO) Terhadap Return On Assets (ROA)}

BOPO adalah rasio perbandingan antara Biaya Operasional dengan Pendapatan Operasional, semakin rendah tingkat rasio BOPO berarti semakin baik kinerja manajemen bank tersebut, karena lebih efisien dalam menggunakan sumber daya yang ada di perusahaan. Semakin kecil rasio ini berarti semakin efisien biaya operasional yang dikeluarkan bank yang bersangkutan sehingga kemungkinan suatu bank dalam kondisi bermasalah semakin kecil. Rasio ini sering juga disebut sebagai rasio efisiensi yang digunakan untuk mengukur kemampuan manajemen bank dalam mengendalikan biaya operasional terhadap pendapatan operasional. Aini (2013). Menurut Dewi, dkk (2015) serta Fajari dan Sunarto (2017) menyatakan bahwa BOPO berpengaruh signifikan negatif terhadap ROA. Maka diduga Biaya Operasional dibandingkan Pendapatan Operasional (BOPO) secara parsial berpengaruh terhadap Profitabilitas pada Bank Umum yang Listed di Bursa Efek Indonesia Periode 20142018.

\section{Pengaruh Loan to Deposit Ratio (LDR) Terhadap Return On Asset (ROA)}

Loan to Deposit Ratio (LDR) adalah perbandingan kredit yang diberikan terhadap dana pihak ketiga. Semakin besar rasio ini mengindikasikan bank itu semakin agresif likuiditasnya, sebaliknya semakin kecil rasio ini juga semakin banyak dana pihak ketiga yang tidak digunakan untuk penempatan kredit (banyak dana menganggur). Oleh karena itu besarnya LDR menurut peraturan pemerintah maksimum 110\% (Kasmir, 2010:225). Menurut Dendawijaya (2003:118) LDR adalah rasio antara seluruh jumlah kredit yang diberikan bank dengan dana yang diterima oleh bank. Mismiwati (2016), Harun (2016) menyatakan bahwa LDR berpengaruh signifikan terhadap ROA. Maka diduga Loan to Deposit Ratio (LDR) secara parsial berpengaruh terhadap Profitabilitas pada Bank Umum yang Listed di Bursa Efek Indonesia Periode 2014-2018.

\section{Pengaruh Non Performing Loan (NPL) Terhadap Return On Asset (ROA)}

Perkembangan pemberian kredit yang paling tidak menggembirakan bagi pihak bank adalah apabila kredit yang diberikannya ternyata menjadi kredit bermasalah. Hal ini terutama 
disebabkan oleh kegagalan pihak debitur memenuhi kewajibannya untuk membayar angsuran (cicilan) pokok kredit beserta bunga bunga yang telah disepakati kedua belah pihak dalam perjanjian kredit (Dendawijaya, 2003:85). Rasio NPL adalah perbandingan antara kredit bermasalah terhadap total kredit. Rasio ini menunjukkan kemampuan manajemen bank dalam mengelola kredit bermasalah. Semakin tinggi rasio ini maka akan semakin buruk kualitas kredit bank yang berarti jumlah kredit bermasalah semakin besar, sehingga kemungkinan suatu bank dalam kondisi bermasalah semakin besar. Semakin besar NPL, akan mengakibatkan menurunnya ROA yang juga berarti kinerja keuangan bank yang menurun. Begitu pula sebaliknya, jika NPL turun, ROA akan semakin meningkat dan kinerja keuangan bank dapat dilakukan semakin baik. Menurut Purwoko dan Sudiyatno (2013) dan Eng (2013) menyatakan bahwa NPL berpengaruh signifikan terhadap ROA. Maka diduga Non Performing Loan (NPL) secara parsial berpengaruh terhadap Profitabilitas pada Bank Umum yang Listed di Bursa Efek Indonesia Periode 2014-2018

$\mathrm{H} 1$

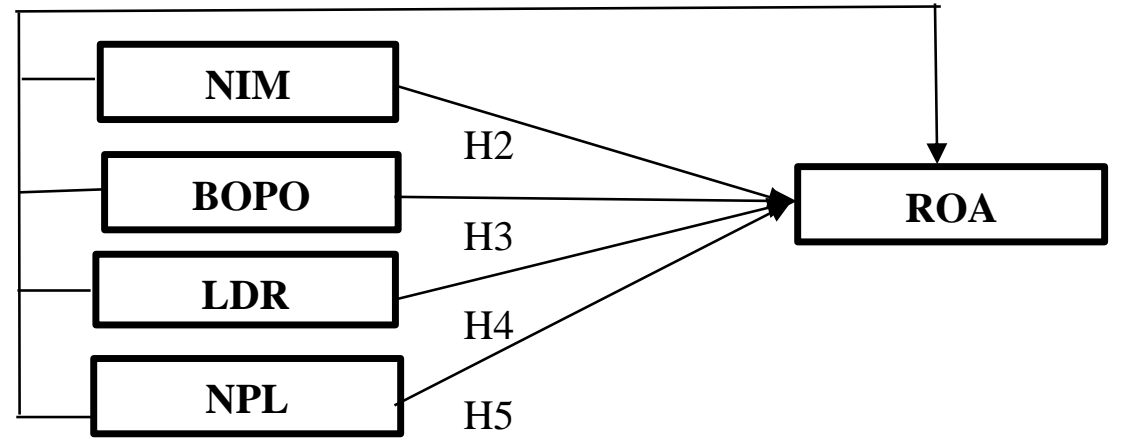

Sumber : Luh Eprima Dewi, dkk (2015), Daniel Sinung K.P, dkk (2016), Rohmiati (2018) Gambar 2 Kerangka Pemikiran Teoritis

\section{METODE PENELITIAN}

\section{Metode Analisis}

Metode analisis data yang digunakan berupa uji statistik deskriptif, Uji Normalitas, Uji Asumsi Klasik (Uji Multikoleniaritas, Uji Heteroskedastisitas dan Uji Autokorelasi), Uji Kelayakan Model (Uji Statistik F, Uji Statistik t, dan Uji Koefisien Determinasi $\left(\mathrm{R}^{2}\right)$.

\section{HASIL DAN PEMBAHASAN}

\section{Statistik Deskriptif}

Statistik deskriptif memberikan gambaran atau deskripsi suatu data yang dilihat dari nilai rata-rata (mean), standar deviasi, varian, maksimum, minimum, sum, range, kurtosis dan 
skewness (kemencengan distribusi) (Ghozali, 2018: 19). Analisis statistik dalam penelitian ini dapat dilihat pada tabel berikut ini :

Tabel 1 Statistik Deskriptif

\begin{tabular}{|l|c|c|c|c|c|}
\hline \multicolumn{7}{|c|}{ Descriptive Statistics } \\
\hline & $\mathrm{N}$ & Minimum & Maximum & Mean & Std. Deviation \\
\hline ROA & 65 & -4.89 & 4.73 & 1.9889 & 1.43906 \\
\hline NIM & 65 & 2.83 & 8.51 & 5.4269 & 1.37526 \\
\hline BOPO & 65 & 58.24 & 150.77 & 80.8374 & 13.63818 \\
\hline LDR & 65 & 76.77 & 108.86 & 90.2608 & 6.85189 \\
\hline NPL & 65 & .60 & 8.83 & 2.8718 & 1.49153 \\
\hline $\begin{array}{l}\text { Valid N } \\
\text { (listwise) }\end{array}$ & 65 & & & & \\
\hline
\end{tabular}

Sumber: Data diolah (2019)

\section{Uji Normalitas}

Hasil perhitungan Skweness, dapat diketahui ZSkewness sebesar 0,872 lebih kecil dari $\mathrm{Z}$ tabel 1,96 dengan signifikansi 0,05. Jadi dapat disimpulkan, bahwa data residual terdistribusi secara normal. Hal ini konsisten dengan hasil uji grafik histogram.

\section{Uji Asumsi Klasik}

\section{Uji Multikolinearitas}

Hasil uji multikoleniaritas diatas menunjukkan bahwa tidak ada nilai tolerance dibawah 0,10 (nilai tolerance berkisar antara 0,344 sampai 0,940), begitu juga dengan nilai Variance Inflation Factor (VIF), tidak ada nilai VIF di atas 10 ( nilai VIF berkisar antara 1,064 sampai 2,910) sehingga dapat disimpulkan bahwa tidak terjadi multikolinearitas antar variabel independen. Hasil ini konsisten dengan hasil uji menggunakan matrik korelasi.

\section{Uji Heteroskedastisitas}

Berdasarkan hasil tampilan output SPSS menunjukkan bahwa tidak ada satupun variabel independen yang signifikan secara statistik mempengaruhi variabel dependen nilai Absolut Res1 (AbsRes). Hal ini terlihat dari probabilitas signifikansinya diatas 5\%. Jadi dapat disimpulkan tidak ada heteroskedastisitas. Hasil ini konsisten dengan uji grafik scatterplot.

\section{Uji Autokorelasi}

Hasil Uji Run Test menunjukkan bahwa nilai adalah 0.00507 dengan probabilitas 0.533 signifikan pada 0.05 sehungga dapat disimpulkan bahwa residual random atau tidak terjadi autokorelasi antar nilai residual.

\section{Uji Regresi Linier Berganda}

Berdasarkan Hasil perhitungan analisis regresi linier berganda dapat disusun persamaan regresi linier berganda sebagai berikut:

ROA $=8,506+0,208 \mathrm{NIM}-0,094 \mathrm{BOPO}-0,002 \mathrm{LDR}+0,041 \mathrm{NPL}+\mathrm{e}$ 


\section{Koefisien Determinasi $\left(\mathbf{R}^{2}\right)$}

Berdasarkan hasil output SPSS, menunjukkan nilai adjusted $R^{2}$ sebesar 0,976. Hal ini berarti 97,6\% Return On Assets (ROA) dapat dijelaskan oleh empat variabel independen (Net Interest Margin, Biaya Operasional dibandingkan Pendapatan Operasional, Loan to Deposit Ratio, dan Non Performing Loan). Sedangkan sisanya $(100 \%-97,6 \%=2,4 \%)$ dijelaskan oleh sebab-sebab yang lain diluar model.

\section{Uji Pengaruh Simultan (Uji F)}

Tabel 1 Uji F

\begin{tabular}{|l|l|r|r|r|r|r|}
\hline \multicolumn{2}{|c|}{ ANOVA $^{\text {a }}$} \\
\hline Model & $\begin{array}{c}\text { Sum of } \\
\text { Squares }\end{array}$ & \multicolumn{1}{c|}{ Df } & $\begin{array}{c}\text { Mean } \\
\text { Square }\end{array}$ & F & Sig. \\
\hline \multirow{4}{*}{1} & Regression & 129.557 & 4 & 32.389 & 651.940 & $.000^{\mathrm{b}}$ \\
\cline { 2 - 8 } & Residual & 2.981 & 60 & .050 & & \\
\cline { 2 - 8 } & Total & 132.538 & 64 & & & \\
\hline
\end{tabular}

a. Dependent Variable: ROA

b. Predictors: (Constant), NPL, LDR, NIM, BOPO

Sumber: Data diolah (2019)

Berdasarkan hasil diatas dapat diketahui bahwa nilai $\mathrm{F}_{\text {hitung }}=651,940>\mathrm{F}_{\text {tabel }}=2,53$ atau signifikansi $=0.000<0.05$, yang berarti terdapat pengaruh yang signifikan antara variabel independen (NIM, BOPO, LDR dan NPL) secara simultan terhadap variabel dependen (ROA)

Dengan demikian Net Interest Margin (NIM), Biaya Operasional dibandingkan Pendapatan Operasional (BOPO), Loan to Deposit Ratio (LDR) dan Non Performing Loan (NPL) secara simultan berpengaruh terhadap Profitabilitas pada Bank Umum yang Listed di Bursa Efek Indonesia Periode 2014-2018.

\section{Uji Statistik t}

Tabel 2 Uji t

\begin{tabular}{|c|c|c|c|c|c|c|}
\hline \multicolumn{7}{|c|}{ Coefficients $^{\mathrm{a}}$} \\
\hline \multirow{2}{*}{\multicolumn{2}{|c|}{ Model }} & \multicolumn{2}{|c|}{$\begin{array}{l}\text { Unstandardized } \\
\text { Coefficients }\end{array}$} & \multirow{2}{*}{$\begin{array}{c}\begin{array}{c}\text { Standardize } \\
\mathrm{d} \\
\text { Coefficients }\end{array} \\
\text { Beta }\end{array}$} & \multirow[t]{2}{*}{$\mathrm{t}$} & \multirow[t]{2}{*}{ Sig. } \\
\hline & & B & Std. Error & & & \\
\hline \multirow{5}{*}{1} & (Constant) & 8.506 & .515 & & 16.506 & .000 \\
\hline & NIM & .208 & .025 & .198 & 8.178 & .000 \\
\hline & BOPO & -.094 & .003 & -.890 & -26.956 & .000 \\
\hline & LDR & -.002 & .004 & -.009 & -.438 & .663 \\
\hline & NPL & .041 & .029 & .042 & 1.419 & .161 \\
\hline
\end{tabular}

Sumber: Data diolah (2019) 
Uji t digunakan untuk menguji suatu variabel diterima karena berpengaruh dan signifikan terhadap variabel dependen apabila pada hasil pengujian menghasilkan nilai $t_{\text {hitung }}>t_{t a b e l}$ dan signifikansinya lebih kecil dari 0,05. Berdasarkan tabel di atas, dapat dikatakan bahwa Net Interest Margin (NIM) dan Biaya Operasional dibandingkan Pendapatan Operasional (BOPO) berpengaruh signifikan terhadap Indeks Harga Saham Gabungan (IHSG),

Net Interest Margin (NIM), Biaya Operasional dibandingkan Pendapatan Operasional (BOPO), Loan to Deposit Ratio (LDR) dan Non Performing Loan (NPL) secara simultan berpengaruh signifikan terhadap Profitabilitas pada Bank Umum yang Listed di Bursa Efek Indonesia.

Berdasarkan hasil pengujian, Net Interest Margin (NIM), Biaya Operasional dibandingkan Pendapatan Operasional (BOPO), Loan to Deposit Ratio (LDR) dan Non Performing Loan (NPL) secara simultan berpengaruh signifikan terhadap Profitabilitas pada Bank Umum yang Listed di Bursa Efek Indonesia. Keadaan ini menunjukkan bahwa penggunaan variabel independen Net Interest Margin (NIM), Biaya Operasional dibandingkan Pendapatan Operasional (BOPO), Loan to Deposit Ratio (LDR) dan Non Performing Loan (NPL) relevan digunakan sebagai prediksi dalam menilai variabel dependen Return On Assets (ROA).

Net Interest Margin (NIM) secara parsial berpengaruh signfikan terhadap Profitabilitas pada Bank Umum yang Listed di Bursa Efek Indonesia.

Berdasarkan hasil pengujian, Net Interest Margin (NIM) secara parsial berpengaruh signifikan terhadap Profitabilitas pada Bank Umum yang Listed di Bursa Efek Indonesia. Net Interest Margin (NIM) merupakan rasio yang menunjukkan kemampuan manajemen bank dalam mengelola aktiva produktifnya untuk menghasilkan pendapatan bunga bersih. Pendapatan bunga bersih diperoleh dari pendapatan bunga dikurangi beban bunga (Almilia dan Herdiningtyas, dalam Mismiwati 2016). Semakin besar NIM yang dicapai oleh suatu bank maka akan meningkatkan pendapatan bunga bersih atas aktiva produktif yang dikelola oleh bank yang bersangkutan. Apabila pendapatan bunga bersih bank meningkat maka laba yang diperoleh bank juga akan meningkat yang pada akhirnya akan meningkatkan profitabilitas (ROA) bank.

Biaya Operasional dibandingkan Pendapatan Operasional (BOPO) secara parsial berpengaruh signifikan terhadap Profitabilitas pada Bank Umum yang Listed di Bursa Efek Indonesia.

Berdasarkan hasil pengujian, Biaya Operasional dibandingkan Pendapatan Operasional (BOPO) secara parsial berpengaruh signifikan terhadap Profitabilitas pada Bank Umum yang 
Listed di Bursa Efek Indonesia. Semakin kecil rasio ini berarti semakin efisien biaya operasional yang dikeluarkan bank (Pandia, 2012: 72). Apabila variabel bebas BOPO mengalami penurunan maka profitabilitas (ROA) bank akan meningkat, karena rasio BOPO yang rendah menunjukkan jika bank telah efisien dalam menjalankan aktivitas operasionalnya, dengan menekan biaya operasional untuk mendapatkan peningkatan pendapatan operasional, sehingga bank dapat menghasilkan laba yang tinggi yang pada akhirnya akan meningkatkan profitabilitas (ROA) bank.

Loan to Deposit Ratio (LDR) secara parsial tidak berpengaruh signfikan terhadap Profitabilitas pada Bank Umum yang Listed di Bursa Efek Indonesia.

Berdasarkan hasil pengujian, Loan to Deposit Ratio (LDR) secara parsial tidak berpengaruh signifikan terhadap Profitabilitas pada Bank Umum yang Listed di Bursa Efek Indonesia. Tidak berpengaruhnya LDR terhadap ROA ini disebabkan karena terdapat gap tinggi diantara bank-bank yang beroperasi dalam mengucurkan kredit. Kemungkinan lainnya dana pihak ketiga tidak hanya disalurkan dalam bentuk kredit tetapi bank juga melakukan penanaman dana dalam bentuk aset yang bersifat likuid. Hal tersebut mungkin saja terjadi mengingat besarnya kepemilikan aset dari Bank umum yang menjadi sampel dalam penelitian ini.

Non Performing Loan (NPL) secara parsial tidak berpengaruh signfikan terhadap Profitabilitas pada Bank Umum yang Listed di Bursa Efek Indonesia

Berdasarkan hasil pengujian Non Performing Loan (NPL) secara parsial tidak berpengaruh signfikan terhadap Profitabilitas pada Bank Umum yang Listed di Bursa Efek Indonesia. Hasil penelitian ini menunjukkan bahwa Non Performing Loan (NPL) Bank Umum yang Listed di Bursa Efek Indonesia tidak berpengaruh signifikan terhadap profitabilitas bank. Hal ini disebabkan karena selama periode penelitian Bank Umum yang Listed di Bursa Efek Indonesia mampu menjaga rata-rata ratio NPL sebesar 2,87\% di bawah NPL yang disyaratkan Bank Indonesia yaitu 5\%. Masih rendahnya NPL menyebabkan Bank Umum yang Listed di Bursa Efek Indonesia tidak membentuk biaya pencadangan aktiva produktif yang besar dan nilai Penyisihan Penghapusan Aktiva Produktif (PPAP) masih dapat mengcover kredit bermasalah yang ada.

\section{PENUTUP}

\section{Kesimpulan}

1. Variabel Net Interest Margin (NIM), Biaya Operasional dibandingkan Pendapatan Operasional (BOPO), Loan to Deposit Ratio (LDR) dan Non Performing Loan (NPL) 
secara bersama-sama (simultan) berpengaruh signifikan terhadap Profitabilitas pada Bank Umum yang Listed di Bursa Efek Indonesia Periode 2014-2018.

2. Variabel Net Interest Margin (NIM) secara parsial berpengaruh signifikan terhadap Profitabilitas pada Bank Umum yang Listed di Bursa Efek Indonesia Periode 2014-2018.

3. Variabel Biaya Operasional dibandingkan Pendapatan Operasional (BOPO) secara parsial berpengaruh signifikan terhadap Profitabilitas pada Bank Umum yang Listed di Bursa Efek Indonesia Periode 2014-2018.

4. Variabel Loan to Deposit Ratio (LDR) secara parsial tidak berpengaruh signifikan terhadap Profitabilitas pada Bank Umum yang Listed di Bursa Efek Indonesia Periode 2014-2018.

5. Variabel Non Performing Loan (NPL) secara parsial tidak berpengaruh signifikan terhadap Profitabilitas pada Bank Umum yang Listed di Bursa Efek Indonesia Periode 2014-2018.

\section{Saran}

Peneliti memberikan beberapa saran untuk penelitian selanjutnya dalam topic yang sama sebagai berikut:

1. Penelitian mendatang diharapkan jangka waktu penelitian dapat diperpanjang sehingga akan menghasilkan penelitian yang menunjukkan gambaran kondisi Profitabilitas pada Bank Umum yang Listed di Bursa Efek Indonesia secara luas.

2. Penelitian mendatang diharapkan mampu untuk menambahkan obyek penelitian lebih banyak sehingga tidak terbatas pada Bank Umum yang Listed di Bursa Efek Indonesia.

3. Pada penelitian mendatang diharapkan menambah jumlah variabel penelitian diluar variabel ini agar memperoleh hasil yang lebih bervariatif yang dapat menggambarkan hal-hal apa saja yang dapat berpengaruh terhadap profitabilitas bank.

\section{DAFTAR PUSTAKA}

Aini, Nur. 2013. Pengaruh CAR, NIM, LDR, NPL, BOPO, dan Kualitas Aktiva Produktif Terhadap Perubahan Laba (Studi Empiris Pada Perusahaan Perbankan yang terdaftar di BEI) Tahun 2009-2011. Jurnal Dinamika Akuntansi, Keuangan dan Perbankan, Mei 2013, Vol. 2, No.1. Hal: 14 - 25. ISSN :1979-4878 .

Bank Indonesia. 2011. Surat Edaran Bank Indonesia No. 13/24/DPNP tentang Penilaian Tingkat Kesehatan Bank Umum. Jakarta: Bank Indonesia 2011. Lampiran Surat Edaran Bank Indonesia No. 13/24/DPNP tentang Penilaian Tingkat Kesehatan Bank Umum. Jakarta: Bank Indonesia 
.2012. Kodifikasi Peraturan Bank Indonesia Kelembagaan Penilaian Tingkat

Kesehatan Bank Umum. Jakarta: Bank Indonesia

Christiano Mario, Parengkuan Tommy2 dan Ivonne Saerang. 2014. Analisis Terhadap RasioRasio Keuangan Untuk Mengukur Profitabilitas Pada Bank-Bank Swasta Yang Go Public Di Bursa Efek Indonesia. Jurnal EMBA. Vol.2 No.4. Hal 817-830. ISSN 23031174 .

Darmawi, Herman. 2011. Manajemen Perbankan. Jakarta: Sinar Grafika Offset.

Dendawijaya, Lukman. 2003. Manajemen Perbankan. Jakarta : Ghalia Indonesia.

Dewi , Luh Eprima, dkk. 2015. Analisis Pengaruh NIM, BOPO, LDR, dan NPL Terhadap Profitabilitas (Studi Kasus Pada Bank Umum Swasta Nasional Yang Terdaftar Pada Bursa Efek Indonesia Periode 2009-2013 ). Jurnal Akuntansi Program S1. Volume: 3 No. 1 Tahun 2015 Volume: 3 No. 1 Tahun 2015. Singaraja: Universitas Pendidikan Ganesha.

Eng, Tan Sau. 2013. Pengaruh NIM, BOPO, LDR, NPL \& CAR Terhadap ROA Bank Internasional Dan Bank Nasional Go Public Periode 2007 - 2011. Jurnal Dinamika Manajemen. Vol. 1 No.3 Juli - September 2013 ISSN: 2338 - 123X.

Fahmi, Irham. 2011. Analisis Laporan Keuangan. Bandung: Alfabeta, cv

Fajari, Slamet dan Sunarto.2017. Pengaruh CAR, LDR, NPL, BOPO Terhadap Profitabilitas

Bank ( Studi Kasus Perusahaan Perbankan Yang Tercatat Di Bursa Efek Indonesia Periode Tahun 2011 Sampai 2015 ). Jurnal. Program Pascasarjana. ISBN: 9-789-7936499-93. Semarang: Universitas Stikubank.

Ghozali, Imam. 2018. Aplikasi Analisis Multivariate Dengan Program SPSS. Semarang: Badan Penerbit Universitas Diponegoro.

Jumingan. 2008. Analisis Laporan Keuangan. Jakarta. PT Bumi Aksara.

Kasmir. 2010. Pengantar Manajemen Keuangan. Jakarta: Kencana Prenada Media Group. 2010. Analisis Laporan Keuangan. Jakarta: PT RajaGrafindo Persada.

K.P, Daniel Sinung, dkk. 2016. Analisis Pengaruh NIM, BOPO, LDR dan NPL Terhadap Profitabilitas Pada Bank Pemerintah Dan Bank Umum Swasta Nasional Di Bursa Efek Indonesia. Jurnal Ekonomi dan Kewirausahaan. Vol. 16 No. 1 Maret 2016: 30 - 40.

Mismiwati. 2016. Pengaruh CAR, NIM, BOPO, LDR dan NPL Terhadap ROA (Studi Pada PT. BPD Sumsel Babel). Jurnal I-Finance. Dosen Fakultas

Ekonomi dan Bisnis Islam. Vol. 2. No. 1. Juli 2016. Palembang: UIN Raden Fatah. Munawir. 2007. Analisa Laporan Keuangan. Yogyakarta: Liberty. 
Muttaqin, Husein Fajri. 2017. Pengaruh CAR, BOPO, NPL dan LDR Terhadap ROA Pada Bank Konvensional Di Indonesia (Studi Kasus pada Bank Konvensional yang Terdaftar di BEI). eJournal Administrasi Bisnis, 2017. 5 (4): 1229-1240.ISSN 2355-5408.

Otoritas Jasa Keuangan. Surat Edaran Otoritas Jasa Keuangan Nomor 43 /SEOJK.03/2016 tentang Transparansi Dan Publikasi Laporan Bank Umum Konvensional. Jakarta. 2014. Laporan Keuangan Tahunan. www.ojk.go.id . 2015. Laporan Keuangan Tahunan. www.ojk.go.id 2016. Laporan Keuangan Tahunan. www.ojk.go.id . 2017. Laporan Keuangan Tahunan. www.ojk.go.id . 2018. Laporan Keuangan Tahunan. www.ojk.go.id

Pandia, Frianto. 2012. Manajemen Dana dan Kesehatan Bank. Jakarta: PT Rineka Cipta. Prasanjaya, A.A. Yogi dan Wayan Ramantha. 2013. Analisis Pengaruh Rasio CAR,BOPO, LDR dan Ukuran Perusahaan Terhadap Profitabilitas Bank Yang Terdaftar Di BEI. $\boldsymbol{E}$ Jurnal Akuntansi Universitas Udayana. 230-245. ISSN: 2302-8556.

Prastowo, D. Julianty R. 2011. Analisis Laporan Keuangan Konsep dan Aplikasi. Yogyakarta, Unit Penerbit \& Percetakan AMP YKPN.

Purwoko, Didik dan Bambang Sudiyatno. 2013. Faktor-Faktor YangMempengaruhi Kinerja Bank (Studi Empirik Pada Industri Perbankan Di Bursa Efek Indonesia). Jurnal Bisnis dan Ekonomi (JBE), Maret 2013, Hal. 25 - 39 Vol. 20, No. 125 ISSN: 1412-3126.

Sudiyatno, Bambang dan Jati Suroso. 2010. Analisis Pengaruh Dana Pihak Ketiga, Bopo, Car Dan Ldr Terhadap Kinerja Keuangan Pada Sektor Perbankan Yang Go Public Di Bursa Efek Indonesia (BEI) (Periode 2005-2008. Jurnal Dinamika Keuangan dan Perbankan, Mei 2010, Hal: 125 - 137. Vol. 2, No.2ISSN :1979-4878.

Sugiyono. 2012. Statistika Untuk Penelitian. Bandung: CV Alpabeta.

Sulaiman, Wahid. 2004. Analisis Regresi Menggunkaan SPSS. Andi Offset

Usman Harun. 2016. Pengaruh Ratio-Ratio Keuangan CAR, LDR, NIM, BOPO, NPL

Terhadap ROA. Jurnal Riset Bisnis dan Manajemen. Vol 4 ,No.1, 2016: 67-82.

Vernanda, Shinta Dewi dan Widyarti. 2016. Analisis Pengaruh CAR, LDR, NPL, BOPO, dan SIZE Terhadap ROA (Studi pada Bank Umum Konvensional yang Terdaftar di Bursa Efek Indonesia Periode 2010-2015). Jurnal.Jurusan Manajemen Fakultas Ekonomika dan Bisnis. Volume 5, Nomor 3, Tahun 2016. Halaman 1-13. ISSN (Online): 2337-3792. Semarang: Universitas Diponegoro.

Wahid Sulaiman, 2004, Analisis-Analisis Regresi menggunakan SPSS, Yogyakarta : ANDI. Yuwono, Prapto. 2005. Pengantar Ekonometri. Yogyakarta: Andi Offset. 